NOAA

National Marine

Fisheries Service
Fishery Bulletin

¿ established 1881 \%
Spencer F. Baird

First U.S. Commissione of Fisheries and founder of Fishery Bulletin
Abstract-Age, growth, and monthly reproductive characteristics were determined for the orange-spotted grouper (Epinephelus coioides) from northern Oman. This species is characterized by a prevalence of females (1-11 years old), and males make up $6.5 \%$ of the total sample. Growth parameters indicate a typical pattern for groupers with a low growth coefficient $(K=0.135)$. The trajectory of the von Bertalanffy growth function was almost linear with no evidence of asymptotic growth. Estimates of mortality revealed a low natural mortality of $0.14 /$ year but a high fishing mortality of 0.59 /year. More alarming was the high rate of exploitation (0.81/year), considered unsustainable for a slow-growing grouper. The population off southern Oman is diandric protogynous, and sex change takes place between 449 and $748 \mathrm{~mm}$ in total length (TL) or over a period of 4-8 years. The gonadosomatic index for females showed a short spawning season from March through May, although $\sim 30 \%$ of females were ripe for 7 months of the year. Size and age at $50 \%$ maturity for females was estimated to be 580 $\mathrm{mm}$ TL and 4 years, respectively. We suggest that substantial changes in the management of this species will be vital in sustaining viable populations of orange-spotted grouper and other species of Epinephelidae within Oman.

Manuscript submitted 14 July 2015. Manuscript accepted 21 July 2016. Fish. Bull. 114:490-502 (2016). Online publication date: 13 Sept. 2016. doi: 10.7755/FB.114.4.10

The views and opinions expressed or implied in this article are those of the author (or authors) and do not necessarily reflect the position of the National Marine Fisheries Service, NOAA.

\title{
Demographic profile of an overexploited serranid, the orange-spotted grouper (Epinephelus coioides), from northern Oman
}

\author{
Jennifer L. Mcllwain ${ }^{1,2}$ \\ Aisha Ambu-ali ${ }^{1}$ \\ Nasr Al Jardani ${ }^{1}$ \\ Andrew. R. Halford ${ }^{3}$ \\ Hamed S. Al-Oufi ${ }^{4}$ \\ David A. Feary (contact author) ${ }^{5}$ \\ Email address for contact author: david.feary@nottingham.ac.uk \\ ${ }^{1}$ Department of Marine Science and Fisheries \\ College of Agricultural and Marine Sciences \\ Sultan Qaboos University \\ P.O. Box 34, Al-Khod 123 \\ Sultanate of Oman \\ 2 Department of Environment and Agriculture \\ Faculty of Science and Engineering \\ Curtin University \\ G.P.O Box U1987 \\ Perth, Western Australia 6487, Australia \\ ${ }_{3}$ Marine Science Program \\ Department of Parks and Wildlife \\ Dick Perry Avenue \\ Kensington, Western Australia 6151, Australia \\ ${ }^{4}$ Ministry of Agriculture and Fisheries \\ P.O. Box 1700, Muscat 111 \\ Sultanate of Oman \\ ${ }^{5}$ School of Life Sciences \\ University of Nottingham \\ University Park \\ Nottingham NG7 2RD, United Kingdom
}

The recent increase in demographic analyses of economically important reef fish stocks from the Indo-Pacific region has made a major contribution to our understanding of key population parameters (Ferreira and Russ, 1992; Newman et al., 1996; Russ et al., 1996; Adams et al., 2000; Grandcourt, 2002, 2005; Williams et al., 2003; Pears et al., 2006). What has emerged is increasing evidence that many exploited reef fish species have life history strategies of extended life spans, slow growth, and, in the absence of fishing, an accumulation of older individuals-strategies usually associated with species in temperate $\left(10-25^{\circ} \mathrm{C}\right)$ and deep $(>30 \mathrm{~m})$ waters (Choat and Robertson, 2002; Pears et al., 2006; Wakefield et al., 2013, 2015). Stocks that have such traits present challenges for fisheries managers, especially in developing countries where life history information is rarely collected (Polunin et al., 1996), mostly because of a lack of funding. The presence of these traits may also explain why conventional fisheries management practices have failed, even for sectors that are regulated (Coleman et al., 2000; Sadovy de Mitcheson et al., 2013).

The epinepheline serranids, or groupers, form an important taxonomic group both from a commercial and ecological perspective (Sluka et al., 2001; Sadovy de Mitcheson et al., 2013). However, a suite of life history strategies and certain behavioral traits make most species of grouper susceptible to overfishing. Life-history strategies include slow growth and late-onset reproduction (Manooch, 1987; Pears et al., 2006), 
long life spans (Manooch, 1987; Bullock et al., 1992; Grandcourt, 2005; Wakefield et al., 2015), complex and variable reproductive patterns (Shapiro, 1987; Fennessy and Sadovy, 2002; Rhodes and Sadovy, 2002) including sex change, while traits include a propensity to aggregate during spawning (Colin, 1992; Sadovy et al., 1994; Samoilys and Squire, 1994; Robinson et al., 2015; Tuz-Sulub and Brulé 2015), and a high degree of site fidelity (Zeller and Russ, 1998; Starr et al., 2007; Luckhurst, 2008).

Frequently published low values of natural mortality $(M)$ for grouper indicate that harvesting levels should be set at less than $10 \%$ of the total biomass (Walters and Pearse, 1996; Coleman et al., 2000). However, low rates of $M$ coupled with commonly cited low rates of growth can also lead to "growth overfishing" with resultant truncated size-distributions as fish are unable to grow to their maximum sizes (e.g. Beverton and Holt 1957). It has also been suggested that populations in which sex change is predominately female to male, under a scenario of increased fishing mortality $(F)$, lose reproductive capacity in 2 ways: through selective removal of larger, mostly male individuals that in turn cause sperm limitation (Coleman et al., 1996) and a decrease in the size of females that in turn reduces total fecundity (Sadovy, 1996; Adams et al., 2000; Sadovy de Mitcheson and Liu, 2008).

Hermaphroditism in groupers can be expressed in 1 of 2 ways: as simultaneous, when individuals are capable of reproducing as both male and female, or sequential (the most common mode), when sex change is made from female to male (protogyny) (Smith, 1965; Shapiro, 1987; DeMartini et al., 2011; Wakefield et al., 2015). Protogynous populations can be further characterized on the basis of the sexual pathway of male development. Monandric protogyny occurs when males develop only from females (secondary males) through a transitional phase, whereas diandric protogyny involves 2 pathways for male development: directly from juveniles (primary males) or through sex change from mature females (Reinboth, 1967). To date, most grouper investigated in detail and that belong to the genus Epinephelus have been confirmed to be monandric hermaphrodites (Sadovy et al., 1994; Brulé et al., 2000; Pears et al., 2006; DeMartini et al., 2011; Wakefield et al., 2015). However, increasing evidence indicates that some species are diandric hermaphrodites, such as the catface grouper (Epinephelus andersoni) (Fennessy and Sadovy, 2002), and Sadovy and Colin (1995) confirmed gonochorism, with the potential for protogynous sex change, in the Nassau grouper (Epinephelus striatus). Clearly, the genus shows sexual plasticity in reproductive development, which has a bearing on population persistence and fisheries management.

In Oman, grouper, or hamoor, are considered one of the most economically important groups of finfish in the artisanal fishery and are heavily targeted by fishermen with a variety of fishing gear (Siddeek et al., 1999). One species, the orange-spotted grouper (Epinephelus coioides) occurs primarily in northern Oman along the
Musandam Peninsula, inhabiting deep rocky reefs to depths of $100 \mathrm{~m}$ (Randall, 1995). Fishermen that target this species use semicircular wire basket traps with, a radius of $2.5-3.5 \mathrm{~m}$, and $35-\mathrm{mm}$ wire-mesh. Traps are deployed either from fiberglass boats of 4-10 $\mathrm{m}$ in overall length (and an average of 28 traps were deployed per trip at an average water depth of $70 \mathrm{~m}$ ) or from large wooden dhows $<25 \mathrm{~m}$ overall length (and an average of 75 traps were deployed per trip at an average water depth of $150 \mathrm{~m}$ ) (senior author, unpubl. data). To date, there are no restrictions on fishing effort for this fishery, and therefore no limits on the numbers or size of orange-spotted grouper landed by fishermen. The official fisheries statistics reveal that catches of grouper from Musandam have remained steady since 1993 at an average of 370 metric tons (t) per year $\left(\mathrm{MAF}^{1}\right)$. This catch represents $10.5 \%$ of the total landings of grouper for Oman from 1993 to 2009 (MAF $\left.{ }^{1}\right)$. On the basis of the total landings of grouper in Musandam, the orange-spotted grouper is the thirdmost important species of grouper by numbers and secondmost important by weight (senior author, unpubl. data).

Despite the importance of orange-spotted grouper to both the southeast Asian aquacultural industry and the trade of live reef fish (Grandcourt, 2012), little demographic or reproductive information exists on wild stocks from throughout its geographic range (but see Grandcourt et al., 2005, 2009), with recent calls by the International Union for Conservation of Nature and Natural Resources for further work that would examine the demography and life history of this species (Cornish and Harmelin-Vivien, 2004). The earliest reproductive study produced some evidence of sex change through social control, but it did so for only a few individuals ( $n=6)$ kept in captivity (Quinitio et al., 1997). More recently, Grandcourt et al. (2005, 2009), focusing on populations within the southern Arabian Gulf, and Liu and Sadovy de Mitcheson (2009), through a controlled experiment of hatchery-reared juvenile orangespotted grouper, confirmed diandric protogyny.

The lack of basic biological data on orange-spotted grouper from the Oman region, the recent anecdotal evidence of declines in landings, and concerns over the spread of the trade of live reef fish into the west Indian Ocean prompted the work described here to determine the demographic makeup of orange-spotted grouper in Oman and to characterize the sexuality and spawning times of this species.. Specifically, we set out to describe the age structure, growth parameters, and mortality schedules of the population from northern Oman. In light of the heavy fishing pressure on this species both in Oman and neighboring countries (Grandcourt et al., 2005, 2009), we also discuss potential management strategies that are appropriate for hermaphroditic populations.

\footnotetext{
${ }^{1}$ MAF (Ministry of Agriculture and Fisheries). 2010. Fisheries statistics book 2009, 130 p. [Available from Omani Fisheries Statistic Department, Ministry of Agriculture and Fisheries, P.O. Box 467, Muscat, Sultanate of Oman.]
} 


\section{Materials and methods}

\section{Sampling}

Between May 2004 and August 2005, 214 orange-spotted grouper were purchased at monthly intervals either directly from fishermen or agents at the fish landing site at Dibba, the only landing site on the east coast of the Musandam Peninsula that extends into the Strait of Hormuz at the mouth of the Arabian Gulf (Fig. 1). Sampling took place during the first week of each month. Fish were kept on ice until they were processed, and all fish were measured to the nearest millimeter in total length (TL) and weighed for total wet weight to the nearest gram. An additional 156 individual orange-spotted grouper were weighed and measured at the landing site and included in the length-weight relationship. Because of the difficulty in staging nonripe gonads of grouper macroscopically (Fennessy and Sadovy, 2002), all gonads, ovaries and testes, were removed and weighed to the nearest $0.01 \mathrm{~g}$ and preserved in $10 \%$ formalin solution for later histological preparation. Gutted whole weights (GWs) of fish were also taken. Sagittal otoliths were removed, cleaned in distilled water, and stored dry for subsequent age determination.

\section{Otolith processing and validation of otolith age}

For microscopic examination, one sagittal otolith was weighed (to the nearest $0.001 \mathrm{~g}$ ), then set in Crystalbond ${ }^{2}$ resin (Aremco Products Inc., Valley Cottage, NY) on the edge of a glass microscope slide. A modified grinding wheel, with P600 wet and dry grit paper, was used to grind the otolith as close to the nucleus as possible (Choat et al., 2003). The otolith half was then repositioned in the middle of the slide, with the polished side facedown, and again ground as close to the nucleus as possible. Sectioned otoliths were left on a hot plate at $60^{\circ} \mathrm{C}$ for $1-2 \mathrm{~h}$ until dark brown in color. The age of each individual was determined by counting the annual growth increments under a microscope, with transmitted light at 15-25× magnification. All otoliths were read twice by the senior author using the doubleblind method (Russ et al., 1998). If the 2 readings disagreed by more than one increment, the otolith was read a third time. The otolith was eliminated from the analysis if the third reading differed as well. The date

\footnotetext{
${ }^{2}$ Mention of trade names or commercial companies is for identification purposes only and does not imply endorsement by the authors or the National Marine Fisheries Service, NOAA.
}

of May 1 was assigned as the nominal hatching date for each individual on the basis of the peak spawning period between April and May for orange-spotted grouper from Musandam (Grandcourt et al., 2005, 2009).

Either marginal zone or edge analysis was used to validate the annual deposition of opaque zones on the otoliths of orange-spotted grouper by inferring the time of year that the increments were formed (Radebe et al., 2002). The otolith margin was recorded as either opaque or translucent for $91 \%$ of individuals. To determine the time when deposition took place, the frequency of otoliths with opaque margins was plotted by month.

\section{Determination of sex and maturity stages}

After preservation, gonads were subject to standard histological preparations and examination to assign a sexual and maturity stage to individual fish (West, 1990). A thin, transverse section was taken from the central region of one gonad lobe, dehydrated in a Shandon Citadell 1000 processor (Thermo Fisher Scientific Inc., Waltham, MA), embedded in wax, sectioned at 5-7 $\mu \mathrm{m}$, mounted on a slide, and stained with haematoxylin and eosin stains. Each gonad was assigned to both a maturity stage (Sadovy and Colin, 1995; Adams, 2002; Fennessy and Sadovy, 2002; Pears et al., 2007) from 
one of the following 8 classifications: 1) undetermined inactive female; 2) immature female; 3) mature, resting or inactive female; 4) mature, active female; 5) spent female; 6) transitional individual; 7) immature male; 8) mature, active male. Ovaries were classified by the presence of the most advanced oocyte, regardless of its abundance (West, 1990).

Maturity schedules for female fish were calculated by plotting the percentage of frequency of both mature, active and mature, inactive females by $3-\mathrm{mm}$ size classes and age groups for the entire sampling period. Females whose spawning history could not be determined (undetermined, inactive females) were not included. Ideally, effective maturity estimates are preferred, and those estimates include only females that are sexually active during the spawning period (Pears et al., 2006). However, it was not possible to limit our estimates in this way because very few active females were sampled during the spawning months. A logistic curve was fitted to the data in the following form:

$$
P=1 /\left(1+\exp \left[-r\left(L-L_{\mathrm{m}}\right)\right]\right),
$$

where $r=$ the slope of the curve fitted to $\ln [(1-P) / P]$ versus $T L$;

$P=$ the proportion of mature female fish; and

$L_{\mathrm{m}}=$ the mean length at sexual maturity.

The size $\left(L_{50}\right)$ and age $\left(t_{50}\right)$ at first maturity for females was estimated to be the intercept point at which $50 \%$ of individual fish were mature.

Seasonal reproductive patterns for female fish were calculated by plotting estimates based on the gonadosomatic index (GSI) and the frequency of reproductive stages by month. Because males were sampled rarely, the GSI was calculated only for female fish with the following equation:

$$
G S I=G o n W / G W \times 100,
$$

where Gon $W=$ the gonad wet weight (in grams).

To determine the frequency of reproductive stages each month, only mature, active (ripening, ripe, and running ripe) and mature, inactive (resting) females were included. The relationship between gonad weight and total length and age was explored to determine whether there was a disproportionate increase in gonad weight above size and age at first maturity, as seen in other epinepheline groupers (Pears et al., 2006).

\section{Data analysis}

The relationship between TL and GW was estimated for 371 fish by using linear regression analysis. To linearize the power curve that best described this relationship $\left(G W=\mathrm{a} T L^{\mathrm{b}}\right)$, both variables were transformed by using the natural logorithm of $x, \log _{\mathrm{e}} x$. The line of best fit for the linear relationship was described by

$$
\log _{\mathrm{e}} G W=\log _{\mathrm{e}} a+\log _{\mathrm{e}} T L .
$$

Because of the low numbers of male fish, the von Bertalanffy growth function (VBGF) was fitted to length-at-age data for all sexes combined, by calculating a nonlinear least-squares regression of TL on age:

$$
L_{\mathrm{t}}=L_{\infty}\left(1-\mathrm{e}^{-K\left(t-t_{0}\right)}\right),
$$

where $L_{\mathrm{t}}=$ TL at age $t$;

$L_{\infty}=$ mean asymptotic TL;

$K=$ the growth coefficient; and

$t_{0}=$ the age at which theoretical TL is zero.

The age-based catch curve technique, estimated for all sexes combined, was used to determine the annual instantaneous rate of total mortality $(Z)$. The natural logarithm of the number of fish between each age class was then plotted by age, and the annual instantaneous rate of $Z$ was then taken as the slope of the line of best fit. The first 4 age classes (320-650 mm TL) were not included in this analysis because they represented fish not fully vulnerable to the fishing gear. Calculations of $M$ were made with the equation of Pauly (1980), which incorporates water temperature and the VBGF parameters of $L_{\infty}$ and $K$. A second method for estimating $M$, developed by Hoenig (1983), also was applied by using the general equation

$$
\log _{\mathrm{e}} Z=1.46-1.01\left(\log _{\mathrm{e}} t_{\max }\right),
$$

where $Z$ is analogous to $M$ in an unexploited population.

The mean annual water temperature for Musandam is $26.8^{\circ} \mathrm{C}$ (Wilson ${ }^{3}$ ). The instantaneous mortality rate $(F)$ was estimated by subtracting the estimate of $M$ from $\mathrm{Z}$ estimated as the slope in the descending limb of the age-based catch curve $(F=Z-M)$. An estimate of the rate of exploitation $(E)$ was calculated as $E=F / Z$ :

$$
\ln (M)=0.55-1.61 \ln (L)+1.44 \ln (\operatorname{Linf})+\ln (K) .
$$

To characterize the state of the fishery, the following $F$-based biological reference points were calculated: 0.5 $M$ for a precautionary target $\left(F_{\text {opt }}\right)$ and $0.67 M$ for the mortality limit $\left(F_{\text {limit }}\right)$.

\section{Results}

\section{Age determination and validation}

Annuli (opaque zones that appeared darker than the adjacent translucent ones) were counted on sectioned sagittal otoliths of orange-spotted grouper. Among the opaque zones, the first one was more difficult to define because it was usually much wider than the remainder. Of the 214 sections, 206 were read successfully, with ages of 1-15 years. The presence of an opaque zone at the margin of otolith (identified by edge analysis) indicated that annuli had a strong seasonality in deposition. More than $80 \%$ of all fish sampled from September through December had opaque margins. A lag of 3 months was observed between the peak in seawater

${ }^{3}$ Wilson, S. 2011. Unpubl. data. Five Oceans Environme-
nal Services, Way 3021, Al Qurm, Muscat, Sultanate of Oman 


\section{Table 1}

Number, size frequency (total length [TL] in millimeters), and mean gutted whole weight (GW), with standard errors (SEs), of samples of orange-spotted grouper (Epinephelus coioides) used in this study. Samples were collected in northern Oman between May 2004 and August 2005. $n=$ number of fish sampled.

\begin{tabular}{lrllcl}
\hline Sex & $n$ & TL $_{\text {min-max }}$ & Mean TL (SE) & GW $_{\text {min-max }}$ & Mean GW (SE) \\
\hline Female & 175 & $281-900$ & $589.58(7.21)$ & $250-9436$ & $2680.37(102.06)$ \\
Transitional & 11 & $449-748$ & $646.00(24.60)$ & $1101-5156$ & $3539.27(1452.26)$ \\
Male & 13 & $443-1005$ & $617.54(44.88)$ & $1008-18906$ & $3866.15(327.79)$
\end{tabular}

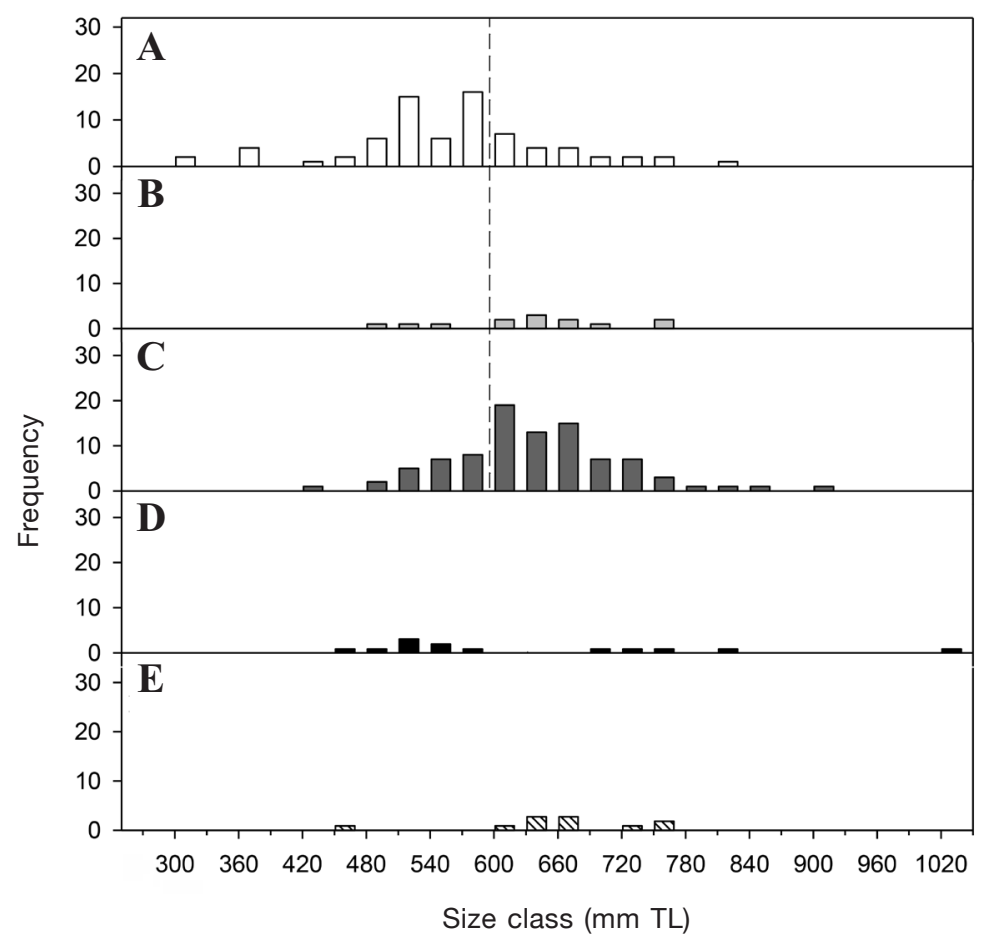

Figure 2

Relationship between size class (total length in millimeters) and frequency of $(\mathbf{A})$ immature female $(n=74),(\mathbf{B})$ undetermined maturitystage female $(n=17),(\mathbf{C})$ mature female $(n=84),(\mathbf{D})$ male $(n=13)$, and (E) transitional phase $(n=11)$ orange-spotted grouper (Epinephelus coioides) within samples collected in northern Oman between May 2004 and August 2005. The dashed line indicates size at maturity.

temperature in June and the formation of the opaque zone at the otolith edge in September.

\section{Size and age distribution}

The relationship between TL and GW for both sexes combined was best described by the equation

$$
G W=5.27^{-6} \times\left(\mathrm{TL}^{3.129}\right),
$$

where the sample size was 356 and the coefficient of determination $\left(r^{2}\right)$ was 0.97 $(P<0.001)$.

Females dominated the sample $(n=178$, $86.5 \%)$ and ranged in size from 281 to $900 \mathrm{~mm}$ TL and in age from 1 to 11 years (average: $589.6 \mathrm{~mm}$ TL [standard error (SE) 7.21]) (Table 1; Fig. 2, A-C; Fig. 3, A-C). More than half the females $(n=77)$ sampled, however, were classified as undetermined, inactive because it was not possible to establish their spawning history. Males composed only $6.5 \%$ of the sampled population, but they were found throughout the size and age classes (Figs. $2 \mathrm{D}$ and $3 \mathrm{D})$. The smallest male was 443 $\mathrm{mm}$ TL and 2 years old, and the largest male was $1005 \mathrm{~mm}$ TL and 15 years old (average:596.4 mm TL[SE 65.40]) (Table 1 ). The male-to-female ratio was $1: 14$. The size and age at sex change was described by a relatively narrow size range (449-748 $\mathrm{mm} \mathrm{TL}$ ) and age range (4-8 years) for transitional individuals (Figs. $2 \mathrm{E}$ and $3 \mathrm{E})$.

\section{Growth models and mortality estimates}

Because of the small number of males that were sampled, the VBGF curve was fitted to all fish, regardless of sex. The plot of size at age revealed a trend in the growth trajectory that was almost linear and had no apparent asymptote (Fig. 4A). Estimates of the VBGF parameters were as follows: $L_{\infty}=927.97 \mathrm{~mm}, K=0.135, t_{0}=$ -2.33. There was a curvilinear relationship between otolith weight and age, best described by the following equation:

$$
\text { Age }=0.101+-0.0023(O W)+0.0017(O W)^{2},
$$

where $O W=$ otolith weight (to the nearest $0.001 \mathrm{~g}$ ) $\left(r^{2}=0.555, n=204\right)$ (Fig. 4B). 


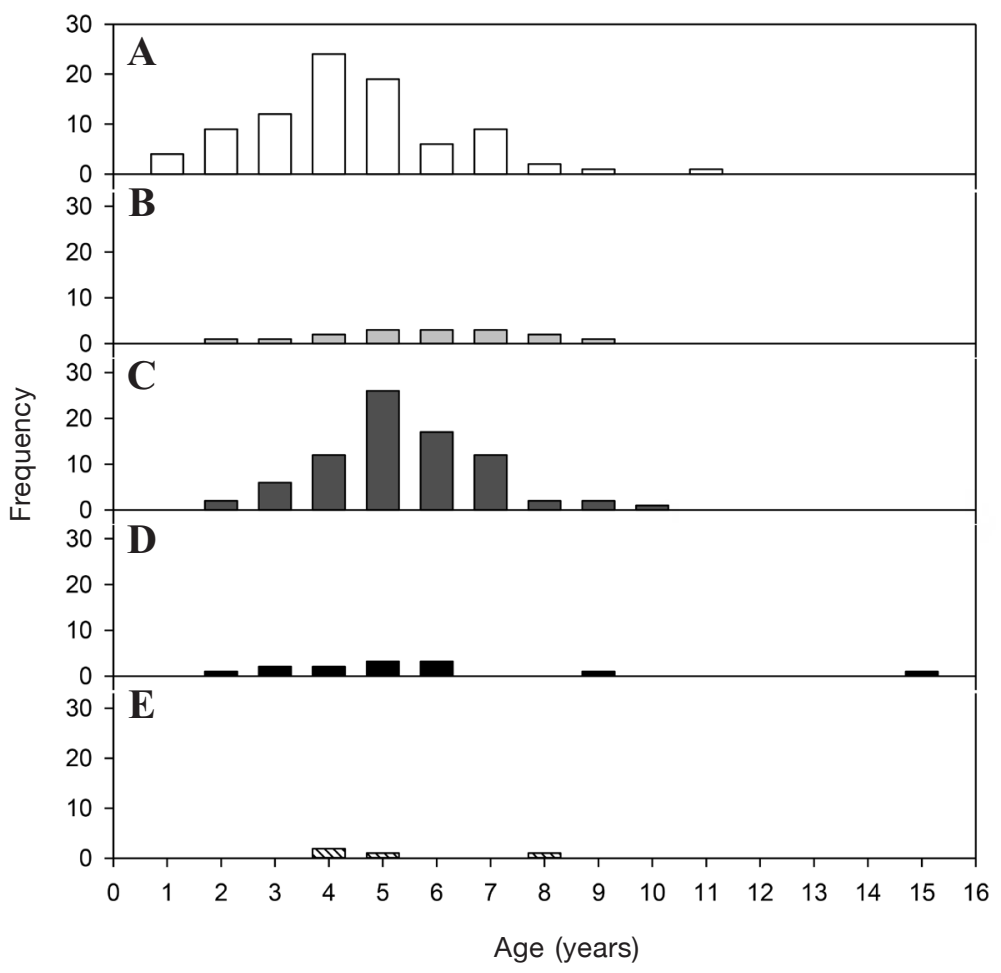

Figure 3

Relationship between age (years) and frequency of (A) immature female $(n=71)$, (B) undetermined female $(n=16)$, (C) mature female $(n=80)$, (D) male $(n=13)$, and (E) transitional phase $(n=11)$ orangespotted grouper (Epinephelus coioides) within samples collected in northern Oman between May 2004 and August 2005.

The instantaneous rate of mortality $(Z)$, estimated with the age-based catch curve, was 0.722/year (Fig. 4C; Table 2). The estimate of $M$ determined from Pauly's (1980) equation was 0.14 /year, which is comparable to the estimate derived from Hoenig's equation (Hoenig, 1983). Although the estimates of $F$ from the 2 methods were similar (0.65/year and 0.59/year, respectively), both values were much greater than the $F_{\text {opt }}$ and $F_{\text {limit }}$ biological reference points. The estimate for $E$ was $0.81 /$ year.

\section{Description of sex and maturation stages}

Females As with most species of Epinephelus described to date, the gonads were fused posteriorly, bilobed, and unequal in size (Sadovy and Colin, 1995; Fennessy and Sadovy, 2002). Ovaries of immature females $(n=71)$ were small, had a thin gonad wall, and lamellae were dominated by gonia and previtellogenic oocytes in the primary growth stage (Fig 5B). Precursory dorsal sperm sinuses were present in $29 \%$ of these individuals. Undetermined, inactive females $(n=17)$ were included as a secondary classification for females for which reproductive history could not be determined. For undetermined, inactive females, gonads were packed with gonia and previtellogenic, primary growth oocytes similar to those found in immature females, and no spermatogenic material was present. The tunica (gonad wall) for these individuals also resembled that of immature individuals. Precursory dorsal sperm sinuses were present in $38 \%$ of undetermined, inactive females (Fennessy and Sadovy, 2002).

The ovaries of mature inactive females $(n=27)$, were larger in diameter than the ovaries of immature females, and they were dominated by previtellogenic oocytes at the cortical alveolar stage, the most advanced stage of oocytes (Fig. 5B). Evidence of recent spawning as a female was provided by the presence of a thick gonad wall and intralamellar muscle bundles in $26 \%$ of mature, inactive females caught during November and December. Mature, active females $(n=57)$ contained oocytes in all stages of development (Fig. 5C). Those females in active vitellogenesis (ripening and ripe) were dominated by oocytes in the cortical alveolus and yolk globule stages, respectively. One spent female was observed (Fig. 5D).

Transitional individuals In gonads of all transitional individuals $(n=11)$, evidence of prior female spawning was found. That evidence included a thick ovarian wall or the presence of intralamellar muscle bundles (scarring) and the occasional presence of brown bodies. Seven individuals were classified as early transitional fish because they contained crypts of primary and secondary spermatocytes or spermatids and oocytes in either the cortical alveoli stage or yolk globule stage (Fig. 6A). There was no evidence of degeneration of either male or female germ cells. In the 4 individuals classified as late-stage transitional fish, degenerating or atretic oocytes in the presence of maturing testicular tissue at differing stages of development were observed (Fig. 6B). The late-stage transitional fish were sampled within the perceived spawning season (March-May). Spermatozoa had not filled the dorsal sperm sinuses of any transitional individual.

Males The gonads of immature males $(n=11)$ were small and compact and while contained the basic structure of an immature female, also had crypts of primary and secondary spermatocytes and spermatids (Fig. 6C). The gonia of 1 individual appeared to be degenerating. There was a relationship between fish size and total area of spermatogenic tissue, with larger fish containing more spermatogenic crypts scattered 

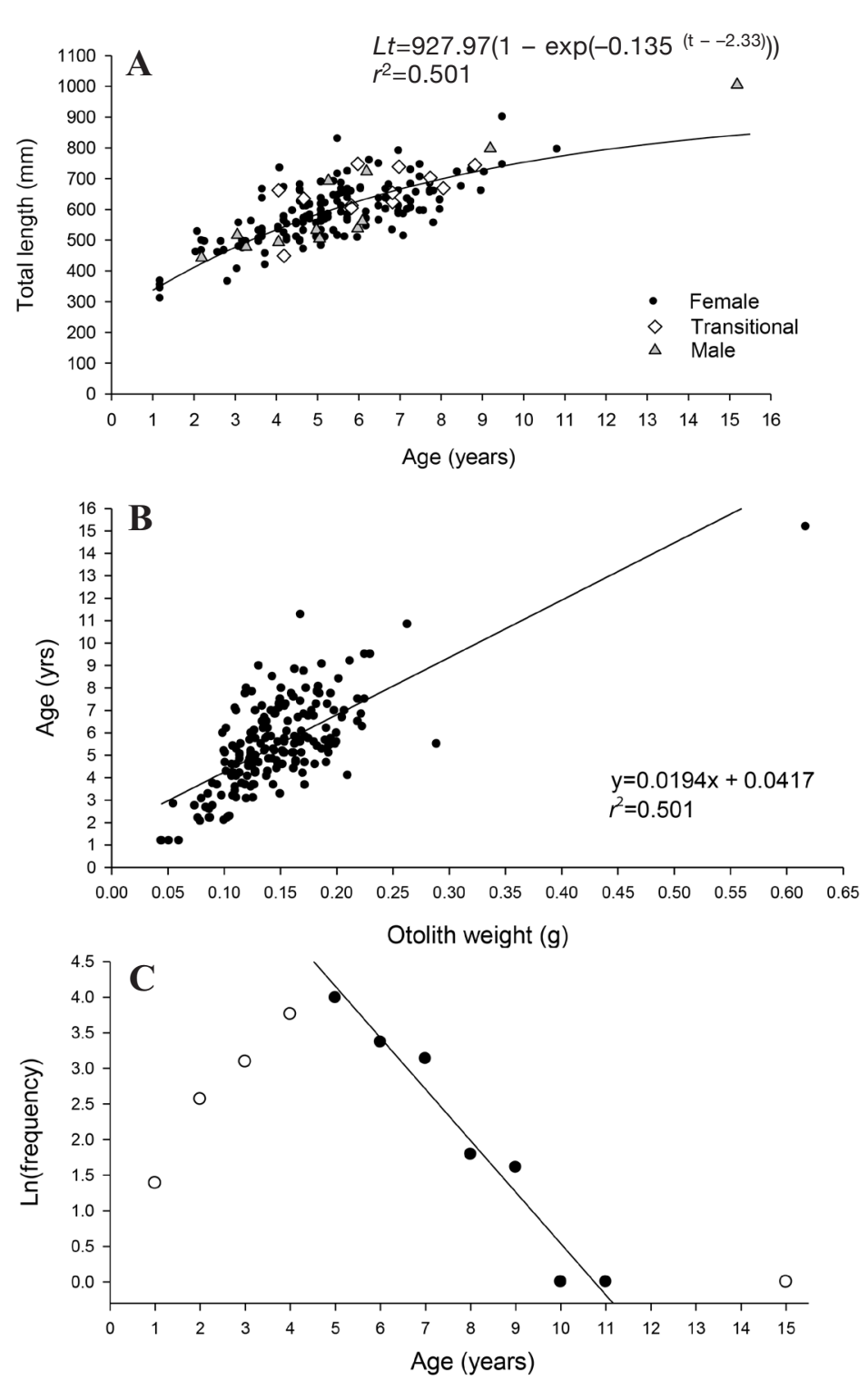

Figure 4

Plots (A) of size at age, (B) of otolith weight against age, and (C) of age against otolith weight for orange-spotted grouper (Epinephelus coioides) collected in northern Oman between May 2004 and August 2005 .

among the previtellogenic oocytes. Dorsal sperm sinuses were present in 4 immature males. Two of these males were primary males with small gonads and no sign of prior female spawning.

In mature active males $(n=2)$, the testes were dominated by spermatogenic tissue and the the sperm sinuses were filled with spermatozoa (Fig. 6D). Primary and secondary spermatocytes and spermatids were also present in both fish. There was no evidence of previtellogenic oocytes in these testes. No spent males were sampled.

\section{Seasonal reproduction}

The GSI for orange-spotted grouper indicated a relatively protracted spawning season that peaks between March and May. A comparison of values from the GSI with data on seawater temperature revealed that the onset of the spawning season in March occurred at the same time that temperatures rose above $26^{\circ} \mathrm{C}$. The plotting of the frequency of mature, active and mature, inactive females by month revealed the timing of reproductive output. During the 3-month peak spawning period, more than $90 \%$ of the sample was composed of mature, active individuals (ripening and ripe), and only one mature, inactive RS female found. In addition, ripe females made up more than $30 \%$ of each of the monthly samples for 7 months of the year, indicating a protracted spawning season beyond the one described by the GSI.

\section{Size and age at maturation}

Plots of age and size frequency for females during the full spawning season (AprilJune) showed a large proportion of immature or undetermined inactive females. By contrast, the numbers of mature inactive females within this period were low. The size and age at 50\% maturity for female orange-spotted grouper sampled throughout the year were estimated to be $580 \mathrm{~mm}$ TL and 4 years, respectively.

\section{Discussion}

The fishery for catch of orange-spotted grouper in northern Oman comprised primarily young, mostly immature females with a maximum age of 11 years. Males were rare and made up only $6.5 \%$ of the sample. We found that this species is slow growing (had a low $K$ ), and produces a VBGF curve best described as linear (with no apparent asymptote). This latter result, coupled with the maximum age (15 years) that is lower than the age of orange-spotted grouper in other locales, indicates that the observed age structure is heavily truncated as a result of overfishing. The histological evidence, based on representative fish from all size classes and samples throughout the year, indicates that the population of orange-spotted grouper from northern Oman is diandric protogynous - a finding that is similar to that from reports on this species within the Arabian Gulf (Grandcourt et al., 2005, 2009). Furthermore, we found through the presence of primary males (smaller males than those at first reproduction) that the devel- 


\section{Table 2}

Estimates of mortality for orange-spotted grouper (Epinephelus coioides) calculated for this study and by Grandcourt (2005) by using methods of Pauly (1980) and Hoenig (1983). Also included are the precautionary biological reference points, precautionary target $\left(F_{\text {opt }}\right)$ and limit $\left(F_{\text {limit }}\right)$, which are based on Hoenig's estimate of natural mortality $(M)$ and exploitation rate.

\begin{tabular}{lcc}
\hline Parameter (value/year) & This study & Grandcourt (2005) \\
\hline Total mortality_(from the catch curve) & 0.72 & 0.97 \\
Natural mortality (Hoenig) & 0.08 & 0.19 \\
Natural mortality (Pauly) & 0.14 & - \\
Fishing mortality (Hoenig) & 0.65 & 0.78 \\
Fishing mortality (Pauly) & 0.59 & - \\
Exploitation rate & 0.81 & 0.80 \\
$F_{\text {opt }}=0.5 M$ (Hoenig) & 0.04 & 0.10 \\
$F_{\text {limit }}=0.67 M$ (Hoenig) & 0.05 & 0.13
\end{tabular}
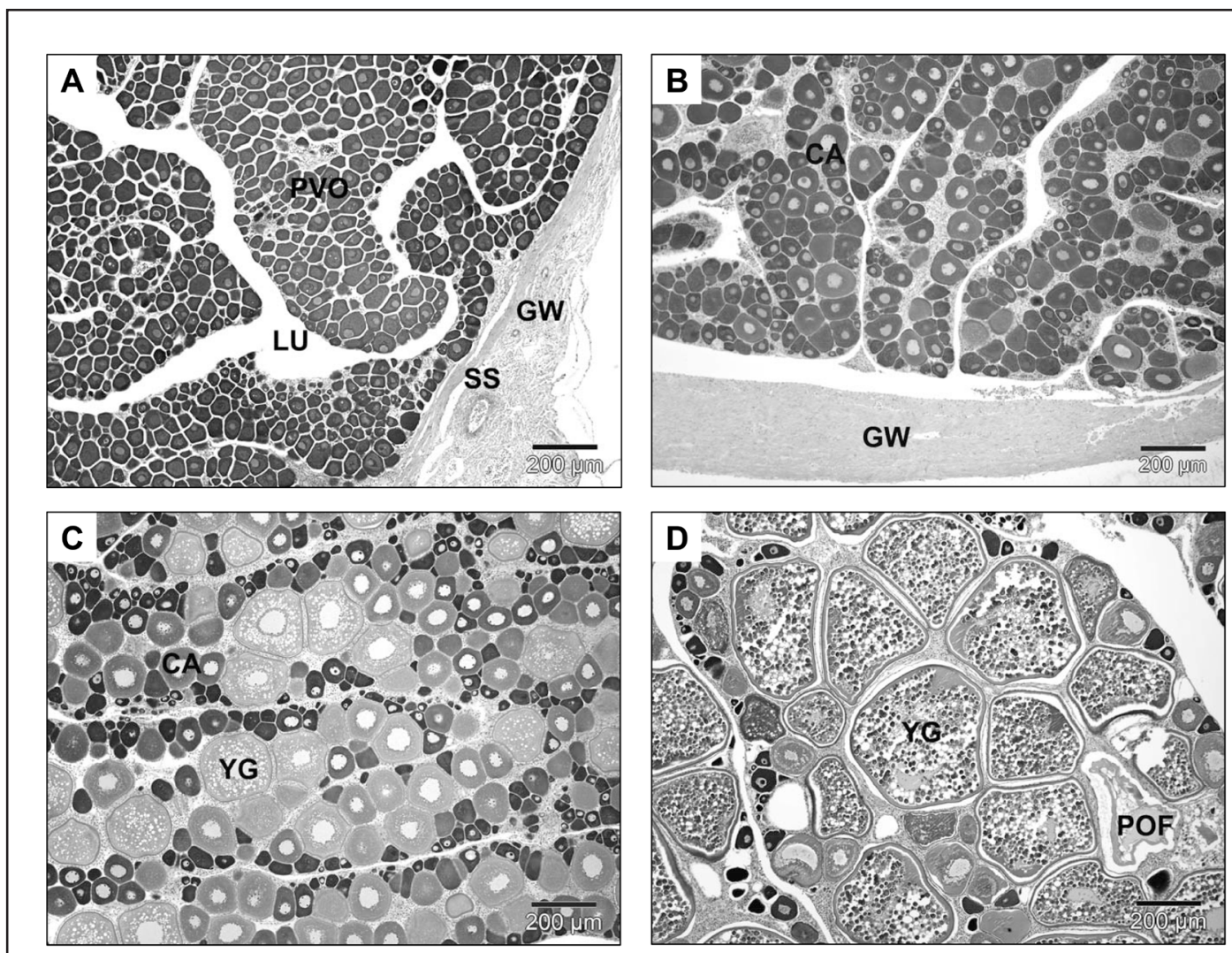

Figure 5

Photomicrographs of histological sections taken from gonads of orange-spotted grouper (Epinephelus coioides) collected in northern Oman between May 2004 and August 2005: (A) immature female gonad, with previtellogenic oocyte (PVO), gonad wall (GW), lumen (LU), and sperm sinus (SS); (B) mature, inactive female gonad, with CA and GW; (C) mature active (ripe) female gonad, with CA and yolk globule stage oocyte (YG); and (D) mature, active (spent) female gonad, with YG and postovulatory follicle (POF). 

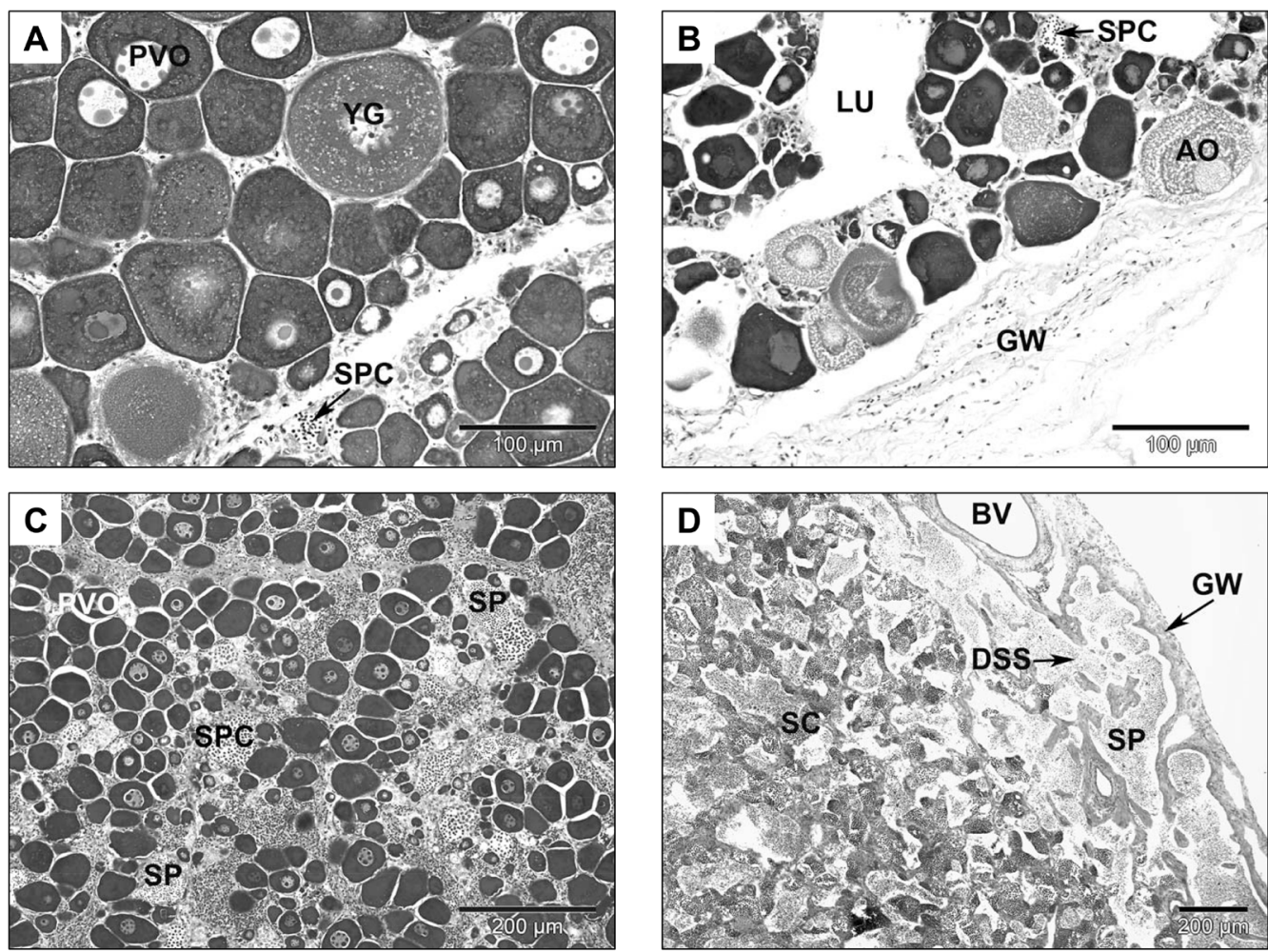

Figure 6

Photomicrographs of histological sections taken from gonads of orange-spotted grouper (Epinephelus coioides) collected in northern Oman between May 2004 and August 2005: (A) early-stage transitional gonad, with previtellogenic oocyte (PVO), yolk globule-stage oocyte (YG), and spermatogenic crypt (SPC); (B) late-stage transitional gonad, with atretic oocyte (AO), lumen (LU), gonad wall (GW), and SPC; (C) immature male gonad, with PVO, SPC, spermatids or spermatozoa (SP); and (D) mature (ripe) male gonad, with dorsal sperm sinus (DSS), spermatocytes (SC), SP, gonad wall (GW), and blood vessel (BV).

opmental pathway of male orange-spotted grouper from Oman is diandric and occurs in one of 2 ways, directly from juveniles or by sex change from fully functioning mature females (Rhodes and Sadovy, 2002).

\section{Demography and fishing impacts}

The demographic characteristics of orange-spotted grouper from Oman were very similar to the characteristics observed in 2 other growth studies of this species conducted in the region (Kuwait: Mathews and Samuel, 1987; Abu Dhabi: Grandcourt, 2005). All the growth parameters, $L_{\infty}(93.07 \mathrm{~cm} \mathrm{TL} ; 97.9 \mathrm{~cm}$ TL), $K(0.1655$; $0.14)$, and $t_{0}(-0.39 ;-1.5)$, for fish in Kuwait and Abu Dhabi were almost identical to the parameters in our results. However, the most significant and perhaps most worrying differences within the Oman population of orange-spotted grouper are the values for the two demographic parameters that are often cited as indicators of overfishing: a reduced maximum age and a truncated age structure. The maximum ages for orange-spotted grouper from the Abu Dhabi study and from our Oman study were 12 and 15 years, significantly lower than the maximum age of 22 years reported for fish from Kuwait during the 1980s (Mathews and Samuel, 1987). Similarly, nearly $23 \%$ of the samples from Kuwait (averaged over 4 years of sampling) represented fish older than 10 years, compared with $0.5 \%$ of the samples from Abu Dhabi (Grandcourt et al., 2005, Grandcourt, 2012) and $2 \%$ of the samples from Oman.

Although it is still not clear how sex change is controlled in orange-spotted grouper, the large size range over which sex change occurs indicates behavioral control, which acts independently of the social group size (Shapiro, 1987). It has been shown that if sex change is controlled by behavior, the removal of the larger, older males through fishing results in rapid sex change by a large female in a group (Huntsman and Schaaf, 1994). Such a compensatory effect means that sex ratios are not necessarily affected by fishing; however, the size 
and age at which sex change occurs is reduced significantly (Adams et al., 2000). For socially mediated sex change to occur, female assessment of either the size (size-ratio assessment) or sex (sex-ratio assessment) of the group is made. In the latter scenario, when males are rare, the numbers of fish undergoing transition increases (Coleman et al., 1996).

Although male orange-spotted grouper were uncommon in the population in northern Oman, there was no evidence that the numbers of transitional fish had increased, and therefore the compensatory mechanism has largely been overridden (Levin and Grimes, 2001). Dramatic reductions in male numbers have previously been documented for gag (Mycteroperca microlepis) and scamp (Mycteroperca phenax) in the Gulf of Mexico, with dire consequences for those populations (Coleman et al., 1996). We argue that the smaller numbers of older fish and secondary males in our sample are not attributed to fishing selectivity (e.g., gear type or depth). Sampling was rigorous and representative of the fishing fleet, which included large wood dhows (>10 m length overall) and small fibreglass boats (4-10 m length overall). Unpublished creel surveys of the Musandam region reveal that dhows are landing the largest individuals because they fish for longer periods in waters up to $300 \mathrm{~m}$ (senior author, unpubl. data). Wire-mesh traps, the most common gear type for this fishery, have an average opening size of 100 cm (Al Masoori et al., 2004), big enough to allow the largest orange-spotted grouper to enter and to ensure that they are vulnerable to being caught by the gear type.

Grouper populations, whose male biomass is eroded through selective fishing, face a significant loss of reproductive output. Although there are no baseline data on the sex ratio of orange-spotted grouper, the males composed $6.5 \%$ of the sampled population, similar to results of study on the Atlantic coast of the United states of male gag, whose numbers declined from $19.6 \%$ to $1.9 \%$ over 12 years (McGovern et al., 1998). A loss of males can seriously affect female reproductive success to the point where some groups of females with limited access to males remain reproductively inactive (Coleman et al., 1996). Limited contact between the sexes also can destabilize social hierarchies (Levin and Grimes, 2001) and, therefore, the overall functioning of the aggregation (Coleman et al., 1996). Historical aggregations of individuals that return each year to spawn in a particular place can be reduced substantially in density if newly recruited fish have no older, experienced fish from which to learn the migration route (Coleman et al., 1996). Future biological monitoring of the population in Oman should include an increased sample size during the spawning season that would allow for detection of nonspawning females. Likewise, a reduction in the male-to-female sex ratio could be a useful indicator of stock recovery after the introduction of regulations, and male biomass can be used as a proxy for reproductive potential (Levin and Grimes, 2001).

\section{Spawning season}

The peak of the spawning season for the Oman population of orange-spotted grouper occurred over a 3-month period from March through May, and there was evidence of protracted spawning across the majority of the year. This spawning period contrasts not only with the spawning periods of populations of orange-spotted grouper in the Arabian Gulf but also with those of a range of other species in the gulf in which spawning periods are much more constrained when compared with the spawning periods of conspecific populations outside the gulf. Populations of the pink ear emperor (Lethrinus lentjan), spangled emperor (L. nebulosus), and black spot snapper (Lutjanus fulviflamma) in the Arabian Gulf all spawn for 2-4 months between April and July (Grandcourt et al., 2006a, 2006b), whereas conspecific populations (pink ear emperor and spangled emperor) within the Indo-Pacific, Indian Ocean, and Red Sea will spawn for the whole year or between August and March (Carpenter and Allen, 1989; Kailola et al., 1993). Such constrained spawning would be expected to be associated with seasonal extremes in water temperature; all spawning of gulf species occurs as water temperatures increase into summer, and spawning ceases during the hottest summer months (August and September).

\section{Implications for the regional and global management of groupers}

There is no evidence to indicate that the structure of stocks of orange-spotted grouper within Oman waters at the time of this writing (2015) is any different from the structure we have presented here (data collected in $2005)$. The high rate of $F$ and high rate of $E$, considered unsustainable for slow growing grouper, are similar to the rates reported for species of grouper worldwide (Sadovy de Mitcheson et al., 2013).

We argue that immediate management of populations of orange-spotted grouper and of species of grouper throughout this region is warranted. However, the management options are limited for the populations of this species (and the majority of species of Epinephelidae) within Oman and the wider Indian Ocean simply because these species predominantly inhabit deep water (Heemstra and Randall, 1993; senior author, unpubl. data). For this group of species, implementing minimum size limits and quotas for catch would be impractical, not only because barotrauma experienced by fish upon release causes a significant rate of mortality but also because this fishery includes a number of different serranid species (senior author, unpubl. data). One management option that has been shown to be useful in a range of regions around the globe is area closure, and we argue that area closures may be an effective management option for this species and species of Epinephelidae because this approach has the potential not only to reduce overall fishing effort but also to protect key benthic habitats (Anderson et al., 2014). 
Closure of the fishery within Oman at certain times of the year, specifically those times associated with the peak spawning period (March-May) may be useful, and the introduction and increased support of no-take zones or marine protected area that encompass critical habitat and aggregation or spawning sites of grouper will be vital for the persistence of viable populations of orange-spotted grouper and other species Epinephelidae within Oman.

\section{Acknowledgments}

This research was made possible by financial aid from the Ministry of Agriculture and Fisheries, Oman (Agricultural Development Fund). We also thank E. Grandcourt and K. Rhodes for earlier discussions at the manuscript stage.

\section{Literature cited}

Adams, S., B. D. Mapstone, G. R. Russ, and C. R. Davies. 2000. Geographic variation in the sex ratio, sex specific size, and age structure of Plectropomus leopardus (Serranidae) between reefs open and closed to fishing on the Great Barrier Reef. Can. J. Fish. Aquat. Sci. 57: 1448-1458. Article

Anderson, A. B., R. M. Bonaldo, D. R. Barneche, C. W. Hackradt, F. C. Félix-Hackradt, J. A. Garcia-Charton, and S. R. Floeter.

2014. Recovery of grouper assemblages indicates effectiveness of a marine protected area in southern Brazil. Mar. Ecol. Prog. Ser. 514:207-215. Article

Beverton, R. and S. J. Holt.

1957. On the dynamics of exploited fish populations. Fish. Invest. Series II, 19, Chapman \& Hall, London.

Brulé, T., T. Colás-Marrufo, A. Tuz-Sulub, and C. Déniel.

2000. Evidence for protogynous hermaphroditism in the serranid fish Epinephelus drummondhayi (Perciformes: Serranidae) from the Campeche Bank in the southern Gulf of Mexico. Bull. Mar. Sci. 66:513-521.

Bullock, L. H., M. D. Murphy, M. F. Goodcharles, and M. E. Mitchell.

1992. Age, growth, and reproduction of jewfish Epinephelus itajara in the eastern Gulf of Mexico. Fish. Bull. 90:243-249.

Carpenter, K. E., and G. R. Allen.

1989. FAO species catalogue, vol. 9. Emperor fishes and large-eye breams of the world (family Lethrinidae). An annotated and illustrated catalogue of lethrinid species known to date. FAO Fish. Synop. 125, 118 p. FAO, Rome.

Choat, J. H., and D. R. Robertson.

2002. Age-based studies. In Coral reef fishes: dynamics and diversity in a complex ecosystem (P. F. Sale, ed.), p.57-80. Academic Press, San Diego, CA.

Choat, J. H., D. R. Robertson, J. L. Ackerman, and J. M. Posada.

2003. An age-based demographic analysis of the Caribbean stoplight parrotfish Sparisoma viride. Mar. Ecol. Prog. Ser. 246:265-277. Article
Coleman, F. C., C. C. Koenig, and L. A. Collins.

1996. Reproductive styles of shallow-water groupers (Pisces: Serranidae) in the eastern Gulf of Mexico and the consequences of fishing spawning aggregations. Environ. Biol. Fish. 47:129-141. Article

Coleman, F. C., C. C. Koenig, G. R. Huntsman, J. A. Musick, A. M. Ecklund, A.M., J. C. McGovern, G. R. Sedberry, R. W. Chapman, and C. B. Grimes.

2000. Long-lived reef fishes: the grouper-snapper complex. Fisheries 25:14-20. Article

Colin, P. L.

1992. Reproduction of the Nassau grouper, Epinephelus striatus (Pisces: Serranidae) and its relationship to environmental conditions. Environ. Biol. Fish. 34:357-377. Article

Cornish, A., and M. Harmelin-Vivien.

2004. Epinephelus coioides. The IUCN Red List of Threatened Species 2004: e.T44674A10934751. [Available at website, accessed November 2015.]

DeMartini, E. E., A. R. Everson, and R. S. Nichols.

2011. Estimates of body sizes at maturation and at sex change, and the spawning seasonality and sex ratio of the endemic Hawaiian grouper (Hyporthodus quernus, F. Epinephelidae). Fish. Bull. 109:123-134.

Fennessy, S. T., and Y. Sadovy.

2002. Reproductive biology of a diandric protogynous hermaphrodite, the serranid Epinephelus andersoni. Mar. Freshw. Res. 53:147-158. Article

Ferreira, B. P., and G. R. Russ.

1992. Age, growth and mortality of the inshore coral trout Plectropomus maculatus (Pisces: Serranidae) from the central Great Barrier Reef, Australia. Aust. J. Mar. Freshw. Res. 43:1301-1312. Article

Grandcourt, E. M.

2002. Demographic characteristics of a selection of exploited reef fish from the Seychelles: a preliminary study. Mar. Freshw. Res. 53123--130. Article

2005. Demographic characteristics of selected epinepheline groupers (Family: Serranidae; Subfamily; Epinephelinae) from Aldabra Atoll, Seychelles. Atoll Res. Bull. 539:201-216.

2012. Reef fish and fisheries in the Gulf. In Coral reefs of the Gulf: adaptation to climatic extremes (B. M. Riegl and S. Purkis, eds.), p. 127-161. Springer, Dordrecht, Netherlands.

Grandcourt, E.M., T. Z. Al Abdessalaam, F. Francis, and A. T. Al Shamsi.

2005. Population biology and assessment of the orange-spotted grouper, Epinephelus coioides (Hamilton, 1822), in the southern Arabian Gulf. Fish. Res. 74:55-68. Article

Grandcourt, E. M., T. Z. Al Abdessalaam, and F. Francis.

2006. Age, growth, mortality and reproduction of the blackspot snapper, Lutjanus fulviflamma (Forsskål, 1775), in the southern Arabian Gulf. Fish. Res. 78:203210. Article

Grandcourt, E. M., T. Z. Al Abdessalaam, A. T. Al Shamsi, and F. Francis.

2006. Biology and assessment of the painted sweetlips (Diagramma pictum (Thunberg, 1792)) and the spangled emperor (Lethrinus nebulosus (Forsskål, 1775)) in the southern Arabian Gulf. Fish. Bull. 104:75-88.

Grandcourt, E. M., T. Z. Al Abdessalaam, F. Francis, A. T. Al Shamsi, S. A. Hartmann.

2009. Reproductive biology and implications for man- 
agement of the orange-spotted grouper Epinephelus coioides in the southern Arabian Gulf. J. Fish Biol. 74:820-841. Article

2011. Demographic parameters and status assessments of Lutjanus ehrenbergii, Lethrinus lentjan, Plectorhinchus sordidus and Rhabdosargus sarba in the southern Arabian Gulf. J. Appl. Ichthyol. 27:1203-1211. Article

Heemstra, P. C., and J. E. Randall.

1993. FAO species catalogue, vol. 16. Groupers of the world (family Serranidae, subfamily Epinephelinae): an annotated and illustrated catalogue of the grouper, rockcod, hind, coral grouper and lyretail species known to date. FAO Fish. Synop. 125, 382 p. FAO, Rome.

Hoenig, J. M.

1983. Empirical use of longevity data to estimate mortality rates. Fish. Bull. 81:898-902.

Huntsman, G. R., and W. E. Schaaf.

1994. Simulation of the impact of fishing on reproduction of a protogynous grouper, the graysby. North Am. J. Fish. Manage. 14:41-52. Article

Kailola, P. J., M. J. Williams, P. C. Stewart, R. E. Reichelt, A. McNee, and C. Grieve.

1993. Australian fisheries resources, 422 p. Bureau of Resource Sciences and Fisheries Research Development Corporation, Canberra, Australia.

Levin, P. S., and C. B. Grimes.

2001. Reef fish ecology and grouper conservation and management. In Coral reef fishes: dynamics and diversity in a complex ecosystem (P. F. Sale, ed.), p.377-389. Academic Press, San Diego, CA.

Liu, M., and Y. Sadovy de Mitcheson.

2009. Gonad development during sexual differentiation in hatchery-produced orange-spotted grouper (Epinephelus coioides) and humpback grouper (Cromileptes altivelis) (Pisces: Serranidae, Epinephelinae). Aquaculture 287:191-202. Article

Luckhurst, B. E.

2008. Site fidelity and return migration of tagged red hinds (Epinephelus guttatus) to a spawning aggregation site in Bermuda. Proc. Gulf Caribb. Fish. Inst. 50:750-763.

Manooch, C. S., III.

1987. Age and growth of the snappers and groupers. In Tropical snappers and groupers: biology and fisheries management (J. J. Polovina and S. Ralston, eds), p. 329374. Westview Press, London.

Mathews, C. P., and M. Samuel.

1987. Growth, mortality and assessments for groupers from Kuwait. Kuwait Bull. Mar. Sci. 9:173-191.

McGovern, J. C., D. M. Wyanski, O. Pashuk, C. S. Manooch II, and G. R. Sedberry.

1998. Changes in the sex ratio and size at maturity of gag, Mycteroperca microlepis, from the Atlantic coast of the southeastern United States during 1976-1995. Fish. Bull. 96:797-807.

Newman, S. J., D. M. Williams, and G. R. Russ.

1996. Age validation, growth and mortality rates of the tropical snappers (Pisces: Lutjanidae) Lutjanus adetii (Castelnau, 1873) and L. quinquelineatus (Bloch, 1790) from the central Great Barrier Reef, Australia. Mar. Freshw. Res. 47:575-584. Article

Pauly, D.

1980. On the interrelationships between natural mortality, growth parameters, and mean environmental tem- perature in 175 fish stocks. J. Cons. Int. Explor. Mer 39:175-192. Article

Pears, R. J., J. H. Choat, B. D. Mapstone, and G. A. Begg.

2006. Demography of a large grouper, Epinephelus fuscoguttatus, from Australia's Great Barrier Reef: implications for fishery management. Mar. Ecol. Prog. Ser. 307:259-272. Article

2007. Reproductive biology of a large, aggregation-spawning serranid, Epinephelus fuscoguttatus (Forsskål): management implications. J. Fish Biol. 71:795-817. Article

Polunin, N. V. C., C. M. Roberts, and D. Pauly.

1996. Developments in tropical reef fisheries science and management. In Reef fisheries (N. V. C. Polunin and C. M. Roberts, eds.), p. 361-377. Chapman and Hall, London.

Quinitio, G. F., N. B. Caberoy, D. M. Reyes Jr.

1997. Induction of sex change in female Epinephelus coioides by social control. Isr. J. Aquac. Bamidgeh 49:77-83.

Radebe, P. V., B. Q. Mann, L. E. Beckley, and A. Govender.

2002. Age and growth of Rhabdosargus sarba (Pisces: Sparidae) from KwaZulu-Natal, South Africa. Fish. Res. 58:193-201. Article

Randall, J.,

1995. Coastal fishes of Oman, 439 p. Univ. Hawaii Press, Honolulu, Hawaii

Reinboth, R.

1967. Biandric teleost species. Gen. Comp. Endocrinol. 9:146A.

Rhodes, K. L., and Y. Sadovy.

2002. Reproduction in the camouflage grouper (Pisces: Serranidae) in Pohnpei, Federated States of Micronesia. Bull. Mar. Sci. 70:851-869.

Robinson, J., N. A. J. Graham, J. E. Cinner, G. R. Almany, and P. Waldie.

2015. Fish and fisher behaviour influence the vulnerability of groupers (Epinephelidae) to fishing at a multispecies spawning aggregation site. Coral Reefs 34:371-382. Article

Russ, G. R., D. C. Lou, and B. P. Ferreira.

1996. Temporal tracking of a strong cohort in the population of a coral reef fish, the coral trout, (Plectropomus leopardus) Serranidae: Epinephaline, in the central Great Barrier Reef, Australia. Can. J. Fish. Aquat. Sci. 53:2745-2741. Article

Russ, G. R., D. C. Lou, J. B. Higgs, and B. P. Ferreira.

1998. Mortality rate of a cohort of the coral trout, Plectropomus leopardus, in zones of the Great Barrier Reef Marine Park closed to fishing. Mar. Freshw. Res. 49:507-511. Article

Sadovy, Y. J.

1996. Reproduction of reef fishery species. In Reef fisheries (N. V. C. Polunin and C. M. Roberts, eds.), p.1559. Chapman and Hall, London.

Sadovy, Y., and P. L. Colin.

1995. Sexual development and sexuality in the Nassau grouper. J. Fish Biol. 46:961-976. Article

Sadovy, Y., A. Rosario, and A. Román.

1994. Reproduction in an aggregating grouper, the red hind, Epinephelus guttatus. Environ. Biol. Fish. 41:269-286. Article

Sadovy de Mitcheson, Y., and M. Liu.

2008. Functional hermaphroditism in teleosts. Fish Fish. 9:1-43. Article 
Sadovy de Mitcheson, Y., M. T. Craig, A. A. Bertoncini, K. E. Carpenter, W. W. L. Cheung, J. H. Choat, A. S. Cornish, S. T. Fennessy, B. P. Ferreira, P. C. Heemstra, et al.

2013. Fishing groupers towards extinction: a global assessment of threats and extinction risks in a billion dollar fishery. Fish Fish. 14:119-136. Article

Samoilys, M. A., and L. C. Squire.

1994. Preliminary observations on the spawning behavior of coral trout, Plectropomus leopardus (Pisces: Serranidae), on the Great Barrier Reef. Bull. Mar. Sci. 54:332-342.

Shapiro, D. Y.

1987. Reproduction in groupers. In Tropical snappers and groupers: biology and fisheries management (J. J. Polovina and S. Ralston, eds.), p. 295-327. Westview Press, London.

Siddeek, M. S. M., M. M. Fouda, and G. V. Hermosa Jr. 1999. Demersal fisheries of the Arabian Sea, the Gulf of Oman and the Arabian Gulf. Est. Coast. Shelf Sci 49:87-97. Article

Sluka, R. D., M. Chiappone, and K. M. Sullivan Sealey. 2001. Influence of habitat on grouper abundance in the Florida Keys, U.S.A. J. Fish Biol. 58:682-700. Article

Smith, C. L.

1965. The patterns of sexuality and the classification of serranid fishes. Am. Mus. Novit. 2207:1-20.

Starr, R. M., E. Sala, E. Ballesteros, and M. Zabala.

2007. Spatial dynamics of the Nassau grouper Epinephelus striatus in a Caribbean atoll. Mar. Ecol. Prog. Ser. 343:239-249. Article

Tuz-Sulub, A., and T. Brulé.

2015. Spawning aggregations of three protogynous grou- pers in the southern Gulf of Mexico. J. Fish Biol. 86:162-185. Article

Wakefield, C. B., S. J. Newman, R. J. Marriott, D. K. Boddington, and D. V. Fairclough.

2013. Contrasting life history characteristics of the eightbar grouper Hyporthodus octofasciatus (Pisces: Epinephelidae) over a large latitudinal range reveals spawning omission at higher latitudes. ICES J. Mar. Sci. 70:485-497. Article

Wakefield, C. B., A. J. Williams, S. J. Newman, M. Bunel, D. K. Boddington, E. Vourey, and D. V. Fairclough.

2015. Variations in growth, longevity and natural mortality for the protogynous hermaphroditic eightbar grouper Hyporthodus octofasciatus between the Indian and $\mathrm{Pa}$ cific Oceans. Fish. Res. 172:26-33. Article

Walters, C., and P. H. Pearse.

1996. Stock information requirements for quota management systems in commercial fisheries. Rev. Fish Biol. Fish. 6:21-42. Article

West, G.

1990. Methods of assessing ovarian development in fishes: a review. Aust. J. Mar. Freshw. Res. 41:199-222. Article

Williams, A. J., C. R. Davies, B. D. Mapstone, and G. R. Russ. 2003. Scales of spatial variation in demography of a large coral-reef fish-an exception to the typical model? Fish. Bull. 101:673-683.

Zeller, D. C., and G. R. Russ.

1998. Marine reserves: patterns of adult movement of the coral trout (Plectropomus leopardus (Serranidae)). Can. J. Fish. Aquat. Sci. 55917-924. Article 